University of New Hampshire

University of New Hampshire Scholars' Repository

Civil and Environmental Engineering

Scholarship

$5-1-2007$

\title{
Leaching Properties of Estuarine Harbor Sediment Before and After Electrodialytic Remediation
}

\author{
Kevin H. Gardner \\ University of New Hampshire, kevin.gardner@unh.edu \\ Gunvor M. Nystroem \\ Technical University of Denmark \\ Deana A. Aulisio \\ University of New Hampshire
}

Follow this and additional works at: https://scholars.unh.edu/civeng_facpub

Part of the Civil and Environmental Engineering Commons

\section{Recommended Citation}

Gardner, K.H., G.M. Nystroem, and D.A. Aulisio, "Leaching Properties of Estuarine Harbor Sediment Before and After Electrodialytic Remediation," Environmental Engineering Science, 24(4): 424-433 (2007).

This Article is brought to you for free and open access by the Civil and Environmental Engineering at University of New Hampshire Scholars' Repository. It has been accepted for inclusion in Civil and Environmental Engineering Scholarship by an authorized administrator of University of New Hampshire Scholars' Repository. For more information, please contact Scholarly.Communication@unh.edu. 


\title{
Leaching Properties of Estuarine Harbor Sediment before and after Electrodialytic Remediation
}

\author{
Kevin H. Gardner, ${ }^{*}$ Gunvor M. Nystroem, ${ }^{2}$ and Deana A. Aulisio ${ }^{1}$ \\ ${ }^{1}$ Environmental Research Group, \\ University of New Hampshire \\ Durham, NH 03824 \\ ${ }^{2}$ Department of Civil Engineering \\ Technical University of Denmark, Kemitorvet \\ Lyngby, Denmark
}

\begin{abstract}
Electrodialytic remediation (EDR) can be used to extract heavy metals from a variety of different media. In this work, contaminated harbor sediments from two locations in the United States and one in Norway were subjected to EDR, and were compared with batch extractions conducted with the sediment. pH-dependent leaching tests were used to evaluate changes in leaching properties of treated and control sediments. Significant fractions of total concentrations were removed during treatment (35-95\% with an average of $75 \%$ for all sediments and elements investigated). The release of elements in $\mathrm{pH}$-dependent leaching tests, however, demonstrated equal or greater leaching from treated sediments in the neutral $\mathrm{pH}$ range. Dissolved organic carbon appears to be a significant contributor to post-treatment increases in leaching, and dissolution of significant iron and aluminum sorption sites is hypothesized to also play a role. This research highlights the importance of understanding contaminant speciation and availability, as total metals concentrations, in this particular case, do not relate to estimates of the environmental availability of metals (total concentrations were typically two to three orders of magnitude greater than concentrations released during $\mathrm{pH}$-dependent leaching).
\end{abstract}

Key words: electrodialytic remediation; electrochemical; $\mathrm{pH}$-dependent leaching; metals; sediment; availability

\section{INTRODUCTION}

Aediment IS DREDGED from harbors to maintain navigational depths. Uncontaminated harbor sediment is most often dumped at sea, whereas contaminated harbor sediment requires alternative end solutions. Current man- agement options include placement in a confined disposal facility (typically adjacent to the waterway), or confined aquatic disposal (buried in sediment underneath a waterway). Beneficial use options require some treatment of contaminated sediments and are still in the development phases, while beneficial use of clean sediment (e.g., to

\footnotetext{
*Corresponding author: Environmental Research Group, 336 Gregg Hall, University of New Hampshire, Durham, NH 03824. Phone: 603-862-4334, Fax: 603-862-3957; E-mail: kevin.gardner@unh.edu
} 
nourish beaches) is standard practice (c.f. Peterson and Bishop, 2005).

Dredged harbor sediment is often contaminated with heavy metals, and remediation technologies (or technologies necessary for the beneficial use of the dredged material) are typically based on soil remediation techniques such as particle size separation, thermal treatment, bioremediation, stabilization/solidification, or washing (c.f. Hisenveld, 1991; Weinstein and Weishar, 2002; Vanthuyne et al., 2003; Dalton et al., 2004; Seidel et al., 2004). Applying existing soil remediation techniques directly to harbor sediment can be difficult, since harbor sediment usually is more fine grained than soil and the heavy metals are generally strongly bound to the high organic fraction and fine particles in sediment (Mulligan et al., 2001).

Electrodialytic remediation (EDR), which was also originally developed for soil remediation, has been shown to be effective for fine-grained material (Ottosen et al., 1997; Pedersen and Gardner, 2003). The method is based on applying an electric current to a contaminated material so that the charged species migrate in the electric field. Removal of the elements is based on charged ions being available in the liquid phase of the contaminated material. Therefore, either water or a desorbing agent is added to the material; a desorbing agent can be an acid, a base, or a complexing agent. When water is mixed with the contaminated material and an electric current applied, acid is produced at the anion exchange membrane. This acid acts to reduce the $\mathrm{pH}$ of the material, which releases elements to migrate in the electric field (Ottosen et al., 2000; Nystroem et al., 2005b). The electrodialytic method has been used at the laboratory scale to remove heavy metals from soil, fly ash, wood waste, and wastewater sludge (Ottosen et al., 2003; Jakobsen et al., 2004). Electrodialytic remediation has been shown to effectively decrease heavy metal concentrations in several harbor sediments, both lightly and heavily contaminated (Nystroem et al., 2003, 2005a; Pedersen and Gardner, 2003), and to be most efficient when material is treated as a slurry (Nystroem et al., 2004). The acidification caused by water splitting at the anion exchange membrane was shown to be just as efficient for the heavy metal removal in electrodialytic remediation as was adding acidic desorbing agents (Nystroem et al., 2006). Knowledge of changes in electrodialytically remediated materials is still limited, however. In particular, it is important to know the potential availability of remaining heavy metals after treatment for reuse and management purposes.

Several different leaching tests have been used to evaluate heavy metal leaching properties for sediments. These tests include investigations of worst-case scenario leaching and leaching caused by specific chemical or physical changes in the sediment (e.g., pH). Leaching of contaminants from sediments is influenced by element chemistry, $\mathrm{pH}$, redox potential, complexation, liquid-to-solid ratio (L/S), contact time, and biological activity (van der Sloot et al., 1996). In the United States, the toxicity characteristic leaching procedure (TCLP) is used to determine whether or not a waste product (including harbor sediment) is considered a hazardous waste (U.S. EPA, 1992; Hardaway et al., 1999). pH-dependent leaching tests have been used to evaluate the potential leaching at different $\mathrm{pH}$ values, and for evaluation of reuse of harbor sediment or products containing harbor sediments (Karius and Hamer, 2001). Sequential extraction has been used to assess in which fractions of the sediment heavy metals are associated (c.f. Chague-Goff, 2005). Results from sequential extraction are used to evaluate potential leaching from disposed sediments and availability of heavy metals in sediments (Stephens et al., 2001).

The aim of this study was to investigate the changes in leaching properties when harbor sediment is electrodialytically treated, and to evaluate the extent to which electrodialytic remediation affects the total concentrations and the availability of several elements. This research used $\mathrm{pH}$-dependent leaching and geochemical speciation modeling to investigate not only changes in total metal content of the sediments from EDR, but also changes in expected environmental behavior of the treated sediments and mechanisms responsible for these changes.

\section{MATERIALS AND METHODS}

\section{Experimental sediment}

Three contaminated sediments were used in this research, one very lightly contaminated and two heavily contaminated. The first originated from Haakonsvern Harbor, Bergen, Norway. The two additional samples originated from the New York/New Jersey harbor. The Gowanus Creek Canal is located in northwestern Brooklyn, New York; and Newtown Creek is the waterway that serves as the border between Brooklyn and Queens. Both of the industrialized, estuarine rivers are contaminated with oil, sewage, PCBs, and heavy metals. The experimental setup has been presented in previous publications (c.f. Nystroem et al., 2005a). Briefly, sediment (100 g dry matter) and water were mixed to the specified L/S in each EDR experiment. The sediment was continuously mixed in a central chamber, and cation and anion exchange membranes separated the sediment/water slurry from catholyte and anolyte compartments where removed elements were concentrated. All three sediments underwent electrodialytic remediation experiments with the following param- 
Table 1. Total elemental concentrations in experimental sediments.

\begin{tabular}{lccccc}
\hline \multicolumn{5}{c}{ Concentration $^{(\mathrm{mg} / \mathrm{kg} \text { dry sediment })^{\mathrm{a}}}$} \\
\hline Constituent & $E R-L^{\mathrm{b}}$ & $E R-M^{\mathrm{c}}$ & $\begin{array}{c}\text { Gowanus } \\
\text { Canal }\end{array}$ & $\begin{array}{c}\text { Newtown } \\
\text { Creek }\end{array}$ & $\begin{array}{c}\text { Haakonsvern } \\
\text { Harbor }\end{array}$ \\
\hline $\mathbf{A s}$ & 8.2 & 70 & 8.5 & 16 & 9.2 \\
$\mathbf{C d}$ & 1.2 & 9.6 & 4.4 & - & 2.3 \\
$\mathbf{C r}$ & 81 & 370 & 75 & 360 & - \\
$\mathbf{C u}$ & 34 & 270 & 240 & 1339 & 39 \\
$\mathbf{N i}$ & 20.9 & 51.6 & 30 & 495 & 19 \\
$\mathbf{P b}$ & 46.7 & 218 & 250 & 636 & 44 \\
$\mathbf{Z n}$ & 150 & 410 & 330 & 1994 & 103 \\
\hline
\end{tabular}

${ }^{\mathrm{a}}$ Measured using EPA 3050B extraction; ${ }^{\mathrm{b}}$ Long and Morgan, 1991; ${ }^{\mathrm{L}}$ Long et al., 1995.

eters: constant current of $50 \mathrm{~mA}\left(1.0 \mathrm{~mA} / \mathrm{cm}^{2}\right), 14$ day duration, and liquid:solid ratio of $4.0 \pm 0.5$.

Solid content and organic fraction were determined according to Standard Methods $2540 \mathrm{~B}$, total solids dried at $103-105^{\circ} \mathrm{C}$, and $2540 \mathrm{E}$, fixed and volatile solids ignited at $500^{\circ} \mathrm{C}$. The solid content of the Gowanus Canal sediment, Newtown Creek, and Haakonsvern sediments was 41,33 , and 34, respectively, and the loss on ignition was 5.7, 4.1, and 25\%, respectively. Particle size distribution of the sediment samples was analyzed using laser diffraction techniques. The average particle size for the NY/NJ Harbor sediments was $14.4 \mu \mathrm{m}$ by volume, with $10 \% \leq 2.8 \mu \mathrm{m}$, and $90 \% \leq 83.1 \mu \mathrm{m}$. The Haakonsvern sediments were also fine grained with $70 \%<63 \mu \mathrm{m}$. The $\mathrm{pH}$ of the three sediments was $6.7,7.1$, and 7.5 , respectively.

"Total" element concentrations in the treated and untreated sediments were determined using EPA SW-846
Method 3050B Acid Digestion of Sediments, Sludges, and Soils. Note that this method is not always a total digestion of the sediment material, but is suggested by the U.S. EPA to represent a conservative estimate of what could potentially be environmentally available. All elemental concentrations were measured in accordance with EPA SW-846 Method 6010B Inductively Coupled Plasma Atomic Emission Spectroscopy and Methods for the Determination of Metals in Environmental Samples (U.S. EPA, 1991). Results for the three sediments are shown in Table 1, along with effects range-low (ERL) and effects range-medium (ERM) values for reference (Long and Morgan, 1991; Long et al., 1995). It should also be noted that, while relatively less contaminated, all of the heavy metals except $\mathrm{Zn}$ in the Haakonsvern sediment were present in concentrations above the OSPAR ecotoxicological assessment criteria. (The 1992 OSPAR Convention is the current instrument guiding interna-

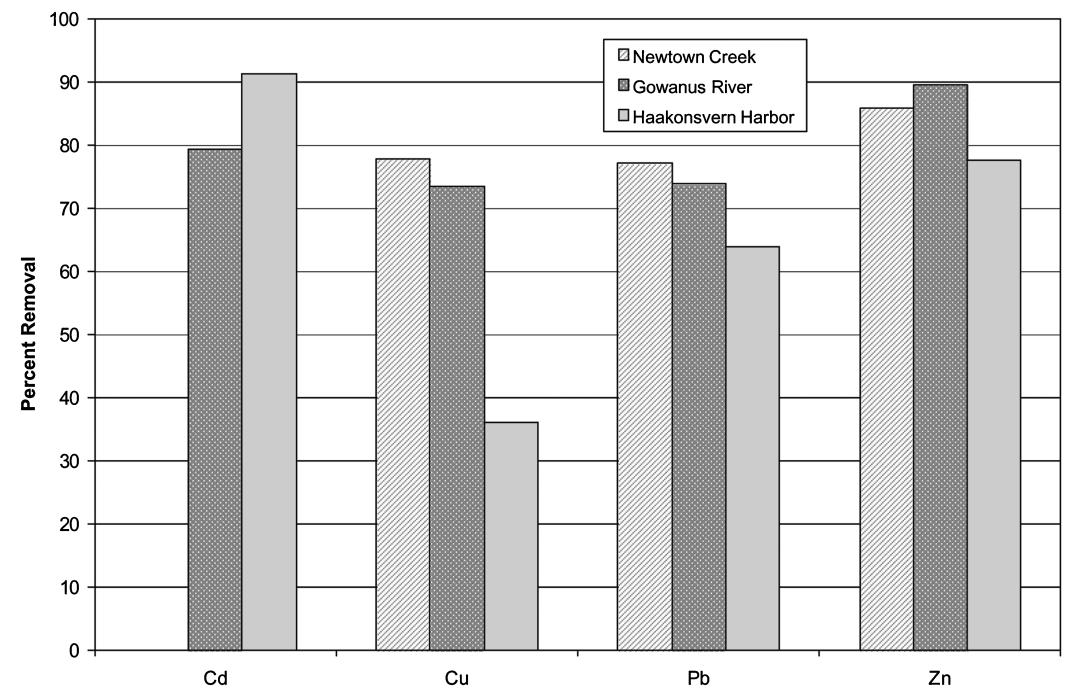

Figure 1. Percent removal of four trace elements following EDR treatment of three contaminated sediments. 
$\mathbf{a}$

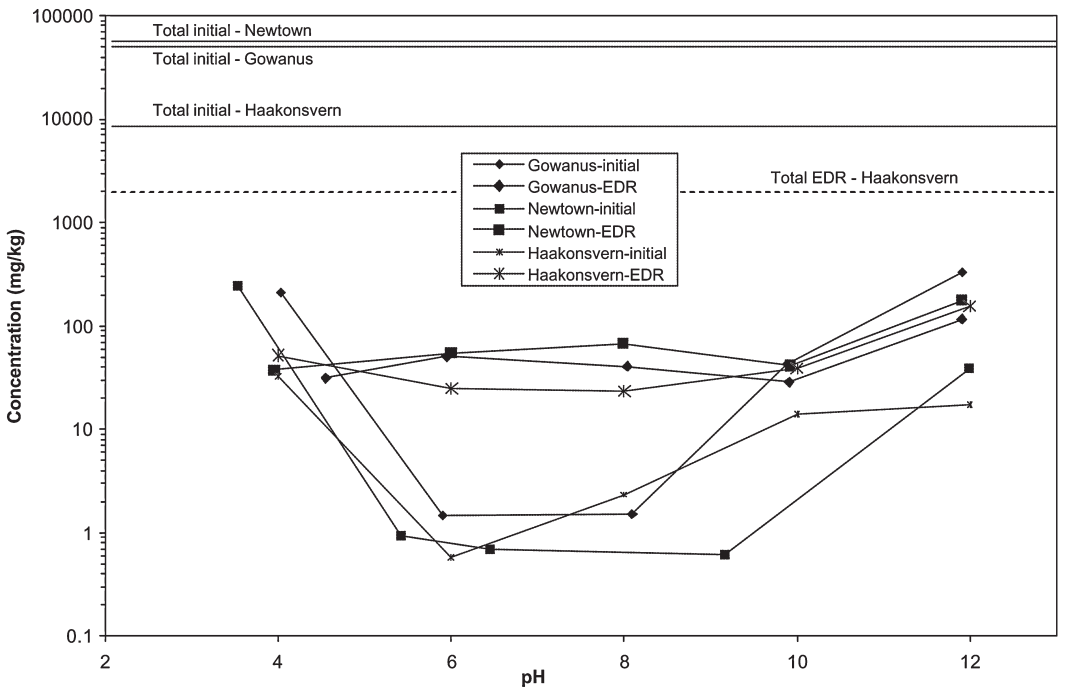

b

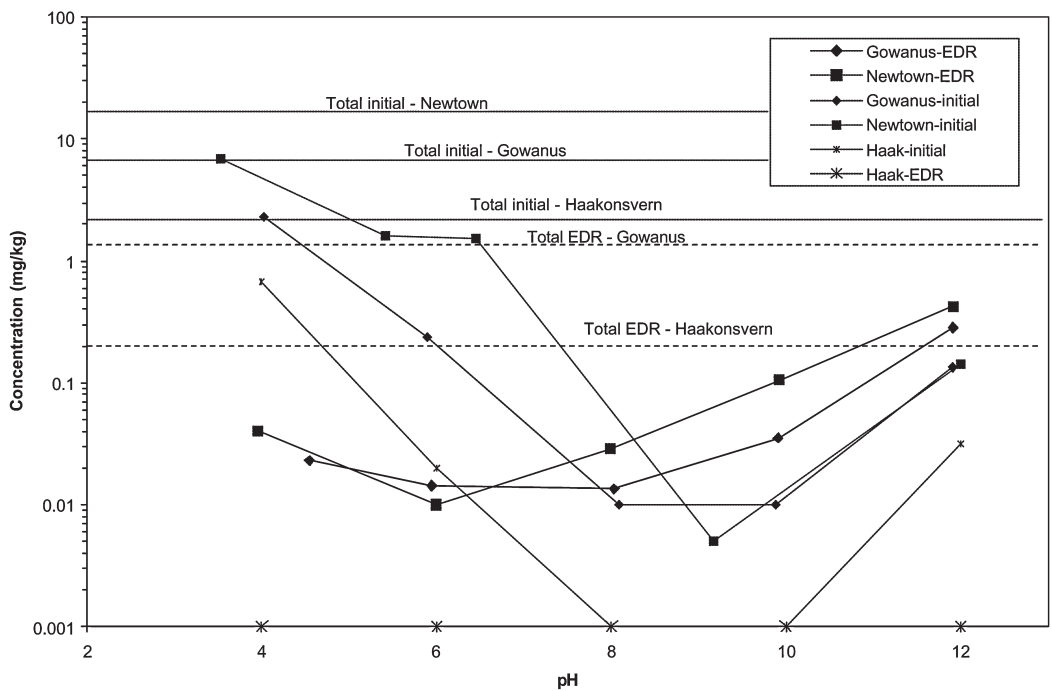

c

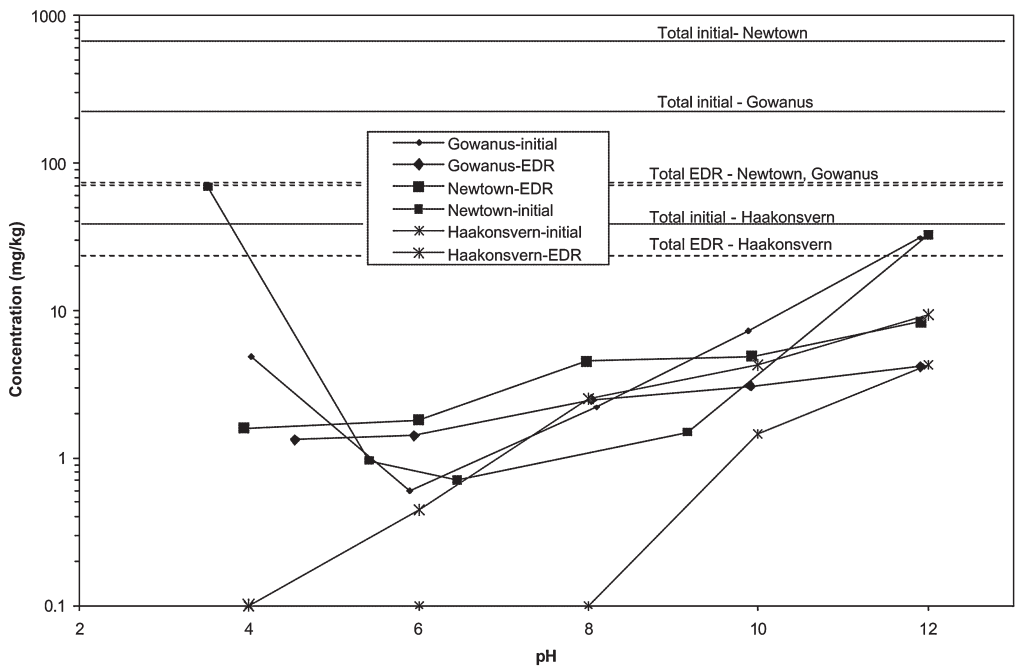

Figure 2. pH-dependent leaching from treated and untreated sediments: (a) Aluminum; (b) cadmium; (c) copper; (d) lead; (e) zinc. 

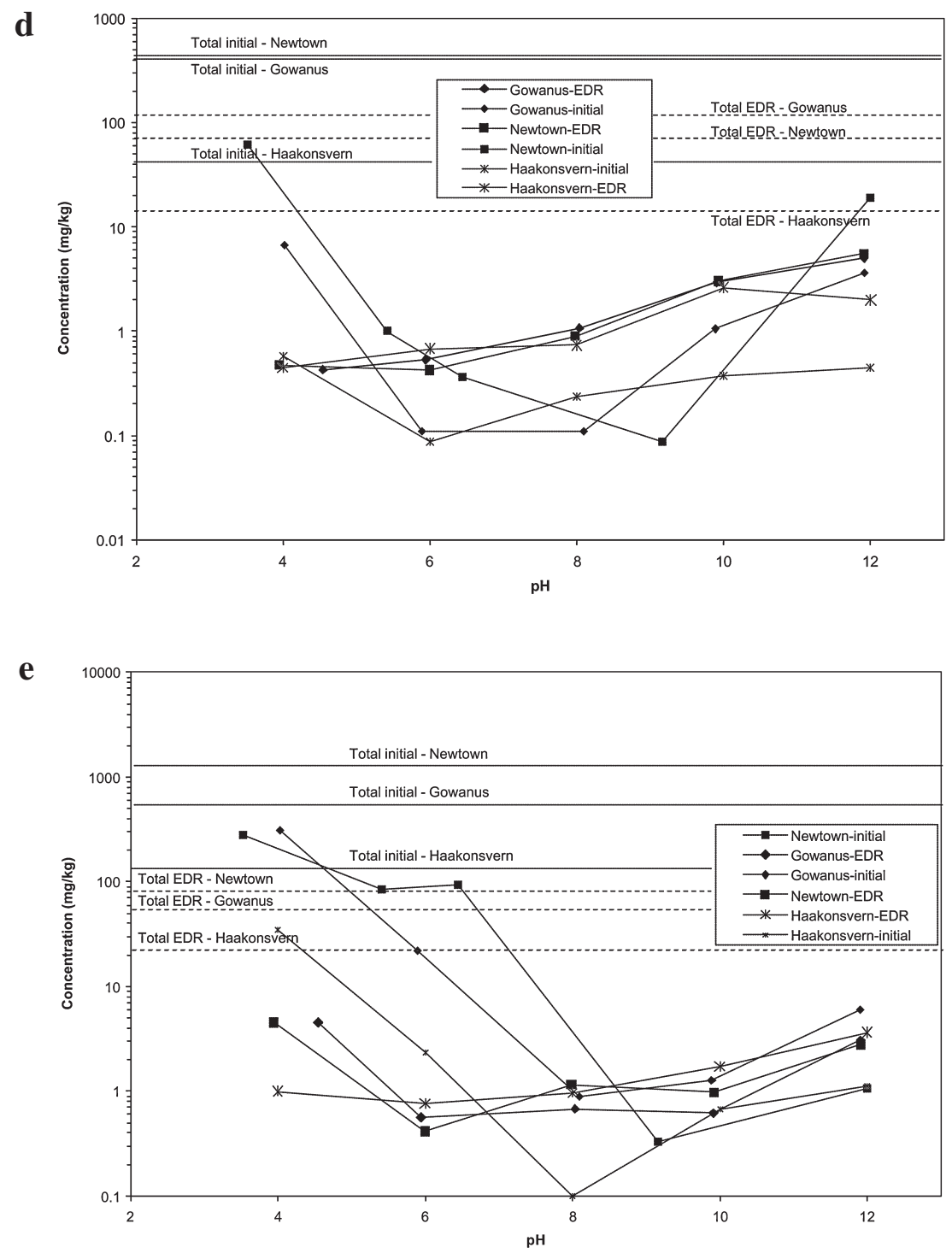

Figure 2. (Cont'd) pH-dependent leaching from treated and untreated sediments: (a) Aluminum; (b) cadmium; (c) copper; (d) lead; (e) zinc.

tional cooperation on the protection of the marine environment of the Northeast Atlantic; OSPAR, 1997.)

\section{Leaching experiments}

pH-dependent leaching. pH-dependent leaching experiments were conducted to investigate the leaching characteristics of elements from the sediments. In a 50$\mathrm{mL}$ Pyrex beaker, $3.0 \mathrm{~g}$ of sediment and $30 \mathrm{~mL}$ of deionized water (L/S 10) were mixed and the beaker sealed. Magnetic stirring was used to keep the sediment suspended. The sediment samples were leached for $24 \mathrm{~h}$ and kept at $\mathrm{pH} 4.0,6.0,8.0,10$, and 12 by using a $\mathrm{pH}$ static controller and an autoburette titrating with $\mathrm{HNO}_{3}$ or
$\mathrm{NaOH}$. At each $\mathrm{pH}$ value, the samples were centrifuged for $15 \mathrm{~min}$ at 5,000 $\mathrm{rpm}$ and the leachate vacuum filtered through a $0.45 \mu \mathrm{m}$ nucleopore filter, acidified with concentrated $\mathrm{HNO}_{3}$, and diluted to $50 \mathrm{~mL}$. All leaching experiments were performed in duplicate, and all samples were stored at $4^{\circ} \mathrm{C}$ until measured by ICP-AES.

\section{RESULTS AND DISCUSSION}

Electrodialytic remediation was carried out on the three sediments. Total concentrations of elements were measured before (in the original sediment) and after EDR. Figure 1 shows the percent of each element removed for 

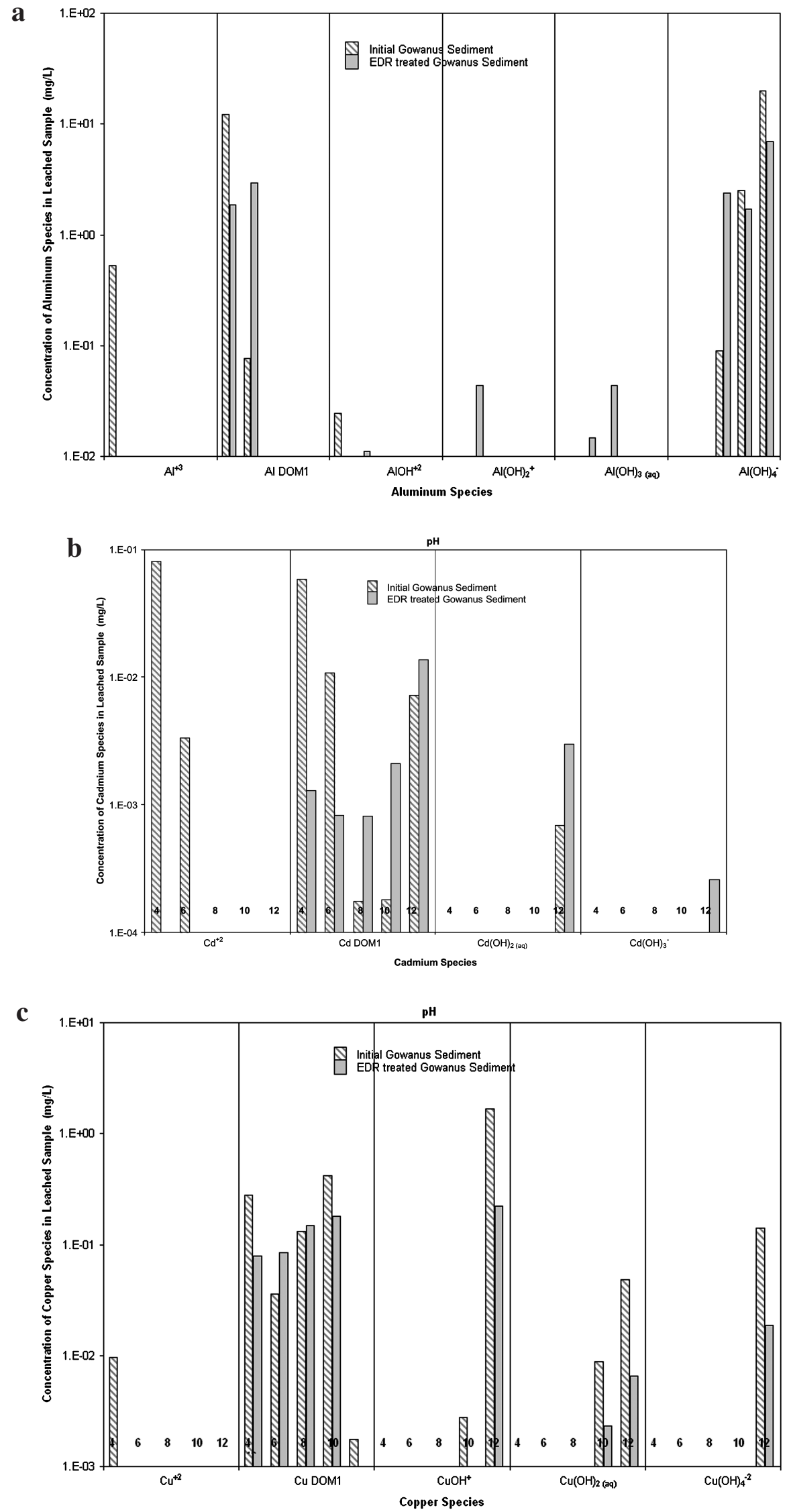

Figure 3. Speciation in Gowanus Canal sediment using visual MINTEQ chemical equilibrium speciation modeling. (a) Aluminum; (b) cadmium; (c) copper; (d) lead; (e) zinc. 

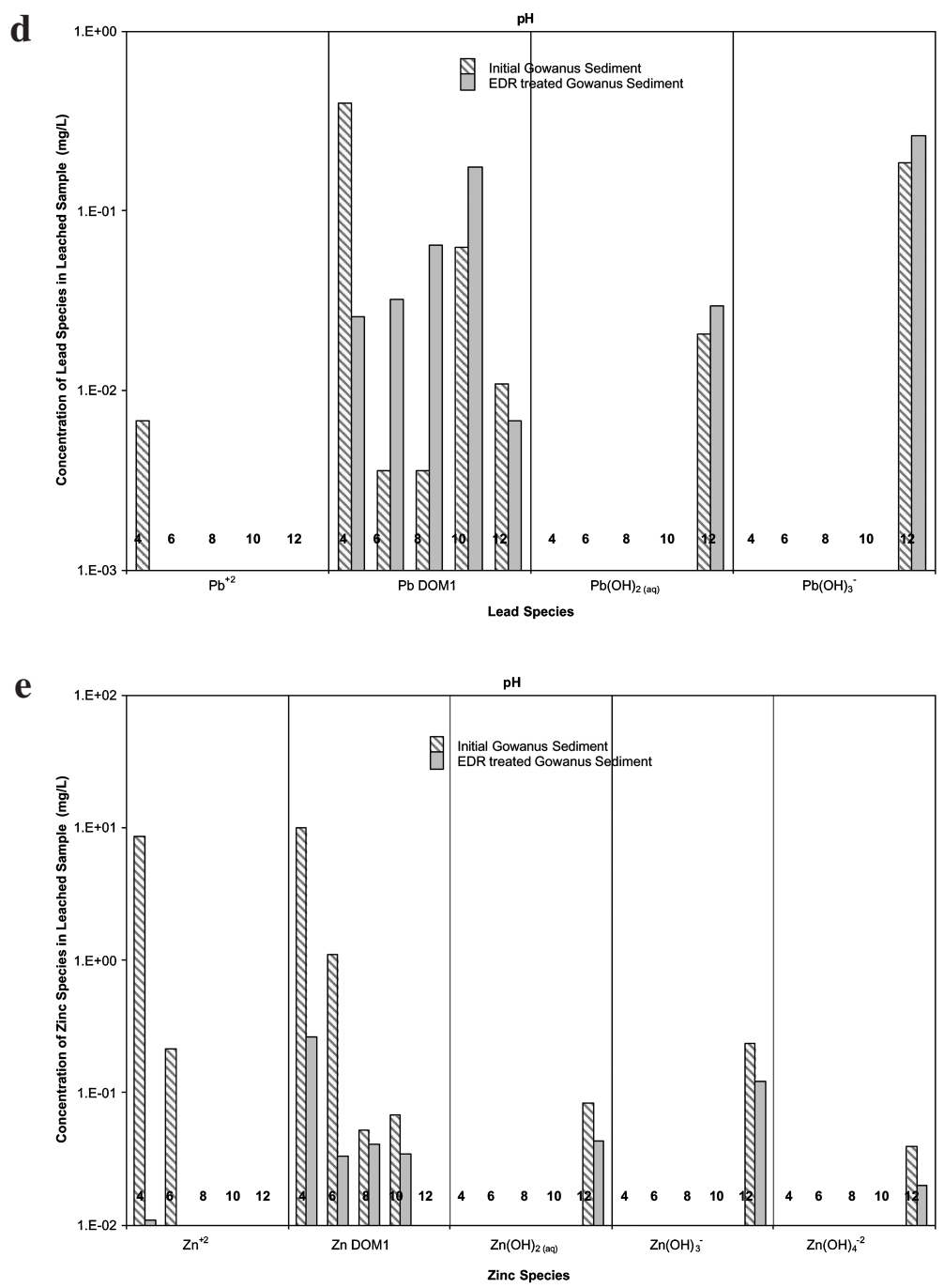

Figure 3. (Cont'd) Speciation in Gowanus Canal sediment using visual MINTEQ chemical equilibrium speciation modeling. (a) Aluminum; (b) cadmium; (c) copper; (d) lead; (e) zinc.

cadmium, copper, lead, and zinc (cadmium removals were not measured in Newtown Creek sediment). For these four elements, high removals were achieved and, in general, more removal was observed in more contaminated sediments. For the trace elements reported here (cadmium, copper, lead, zinc) Newtown Creek has the highest contaminant concentrations followed by the Gowanus Canal and the Haakonsvern Harbor material (see Table 1). These data suggest that the metal present from anthropogenic activities, likely bound in labile phases such as surface complexes on iron and aluminum oxides, surface precipitates, sulfide precipitates, and complexed with natural (particulate) organic matter, is removed more readily from sediment than metals present in concentrations closer to background elemental abundances. It is important to note that these samples were not maintained under anoxic conditions, so the role of sulfide in element speciation is not significant, particularly at the low $\mathrm{pH}$ of the final treated sediments $(\mathrm{pH}$ between 2 and 3 for all sediments).

High removals of total metals concentrations have been demonstrated in contaminated sediment as well as many other types of media using EDR (c.f. Jakobsen et al., 2004; Nystroem et al., 2004). The major purpose of this investigation was to understand how EDR may influence metal availability from the sediment. For remediation to be considered successful, the treated material should release contaminants in lower concentrations in a particular management environment. To investigate the expected environmental behavior of the treated sediment and to achieve an understanding of what may contribute to increased or decreased leaching, $\mathrm{pH}$-dependent leach- 
ing tests were conducted. Again, it is important to note that these tests were conducted under oxic conditions, so precipitation of metal sulfides is not expected to play a role in control of element availability. Figure $2 \mathrm{a}-\mathrm{e}$ presents results of $\mathrm{pH}$-dependent leaching for aluminum, cadmium, copper, lead, and zinc. The figures include the leaching behavior of the original sediment, the treated sediment, and also show the total concentrations measured. In most cases, total concentrations measured by EPA method 3050B are significantly higher than leachate concentrations between $\mathrm{pH} 4$ and 12. Figure 2a shows the $\mathrm{pH}$-dependent leaching behavior of aluminum for the three sediment materials and demonstrates remarkable similarity between all three untreated sediments and all three treated sediments, but very large differences are apparent between treated and untreated sediment. Although aluminum itself is not typically a contaminant of concern, the expected leachate concentrations from EDR treated sediments (approximately $60 \mathrm{mg} / \mathrm{kg}$, corresponding to $6 \mathrm{mg} / \mathrm{L}$ in the $10: 1 \mathrm{~L} / \mathrm{S}$ ratio extract) is significantly above the EPA's secondary drinking water standard of 0.05 to $0.2 \mathrm{mg} / \mathrm{L}$. Moreover, the leaching results suggest that EDR may have a significant impact on mineral phases important for sorption of elements under oxidizing conditions. $\mathrm{pH}$-dependent leaching results for iron were very similar to those of $\mathrm{Al}$, with one to two orders of magnitude greater Fe leaching in treated sediments at $\mathrm{pH}$ values between 6 and 12 (data not shown).

$\mathrm{pH}$-dependent leaching of the four trace elements reported here show many similar features when comparing original sediment to treated sediment behavior. Because the total concentrations have been significantly reduced, the leaching behavior at low $\mathrm{pH}$ values, which typically approach total available metal concentrations, are significantly lower in the treated materials. However, concentrations leached through the neutral and higher $\mathrm{pH}$ ranges show more varied results. For example, cadmium leaching at $\mathrm{pH} 6$ is much higher in the untreated sediments, but at $\mathrm{pH} 8$ the treated sediments release higher concentrations of cadmium, which is a trend that continues at $\mathrm{pH} 10$ and 12. Figure $2 \mathrm{c}$ demonstrates that copper leaching at $\mathrm{pH} 6$ and 8 is greater in the treated sediments than the untreated sediments. This trend is reversed by $\mathrm{pH}$ of 12 , where the untreated sediment again shows higher copper leaching. Similarly, lead demonstrates higher leaching through the neutral $\mathrm{pH}$ range, and zinc demonstrates very similar leaching trends above $\mathrm{pH} 8$. In general, treated sediments demonstrated greater leaching throughout the neutral $\mathrm{pH}$ range, which is important to recognize if the sediment management environment is expected to be circumneutral; greater leaching suggests a potentially counterproductive treatment process.

It has been well established that total concentrations of elements in soil, sediment, or industrial byproducts bear little relationship to concentrations released in leaching tests (c.f. Kosson et al., 2002; Apul et al., 2005). The pH-dependent leaching results presented in Fig. 2 reiterate this observation and make it clear that an understanding of element speciation and processes that may control element release is crucial to evaluating the success of a treatment method.

In order to understand the $\mathrm{pH}$-dependent leaching results presented in Figure 2, equilibrium speciation modeling was conducted using visual MINTEQ v.2.40 (http://www.lwr.kth.se/English/OurSoftware/vminteq/). Measured concentrations at each $\mathrm{pH}$ of all trace species, salts, and dissolved organic carbon were used as input for the speciation modeling. Visual MINTEQ uses the Gaussian DOM model described by Grimm et al. (1991). One DOM component was used in this modeling with the charge on the DOM species determined from visual MINTEQ database values. To evaluate possible solubility controlling mineral phases, mineral phases close to the solubility limits (saturation indices of $0 \pm 2$ ) were input as infinite solid phases one at a time, and resulting aqueous phase concentrations were obtained.

There were no instances where mineral phases could explain the leaching behavior observed across a range of $\mathrm{pH}$ values. The leaching of $\mathrm{Al}$ from untreated sediments agreed well with $\mathrm{Al}(\mathrm{OH})_{3(\mathrm{~s})}$ at high and low $\mathrm{pH}$, although the leached values exceeded predicted values by up to two orders of magnitude at circumneutral $\mathrm{pH}$ values. Many of the trace element species are likely controlled by their respective hydroxides or carbonates, but this is only at the extreme $\mathrm{pH}$ range above 10 or 12 . This information suggests that control of element release in the neutral range is likely related to surface complexation with $\mathrm{Fe}$ and $\mathrm{Al}$ oxide/hydroxide phases. This has been shown to be an important and frequently controlling mechanism in similar studies (c.f. Meima and Comans, 1998; Pempkowiak et al., 1999; Simpson and Batley, 2003).

In order to understand changes in leaching before and after treatment, the major aqueous phase species were plotted as a function of $\mathrm{pH}$; this data is shown in Figure 3a-e for the Gowanus Canal sediments. Figures 3 show the concentration of each species in solution (concentration as the element, not the complex); thus, it is easy to compare each element on a total mass basis for treated and untreated sediments. For example, Figure $3 \mathrm{a}$ for $\mathrm{Al}$ clearly shows that the large change in Al partitioning at $\mathrm{pH} 6$ occurs in association with the dissolved organic carbon (DOC) complex. DOC is generally higher in the treated sediments than the untreated sediment. Similarly, the $\mathrm{Cd}-\mathrm{DOC}$ complex is dominant for $\mathrm{Cd}$ and $\mathrm{Pb}-\mathrm{DOC}$ is dominant for $\mathrm{Pb}$ in the treated sediments at $\mathrm{pH} 8$ and 
10, suggesting the significant role of DOC in the partitioning behavior observed.

The role of surface and DOC complexation in controlling leaching behavior has been observed in other types of systems. Apul et al. (2005) found that solubility behavior could not describe the leaching of elements from steel slag, while surface complexation and precipitation with hydrous ferric and aluminum oxides resulted in satisfactory descriptions for the 12 elements investigated. Meima and Comans (1998) demonstrated the ability of surface complexation with ferric and aluminum hydroxides to describe leaching in weathered municipal solid waste bottom ash, while Van Zomeren and Comans (2004) demonstrated that $\mathrm{Cu}$ complexes leached from municipal solid waste incinerator ash were dominated by $\mathrm{Cu}$ bound to fulvic acid type DOC. In sediments, the majority of research reported in the literature has focused on in situ speciation, where the concentrations of sulfide dominate the observed behavior. A few recent works have investigated the significance of sorption of metals to iron hydroxide in the context of metal bioavailability and oxidation of $\mathrm{Fe}$ (II) in sediment porewater to iron hydroxide; partitioning to iron hydroxide has been identified as a dominant mechanism controlling metal release and bioavailability (Perin et al., 1997; Simpson et al., 2002; Simpson and Batley, 2003; Chaque-Goff, 2005). Because of the demonstrated inability of mineral species to describe leachate concentrations and the significance of DOC complexation, it is hypothesized that sorption to iron and aluminum hydroxides and perhaps particulate organic matter control the leaching from sediments. Posttreatment increases in leaching may be a result of the combined effect of iron and aluminum removal from the system and changes in DOC concentrations.

\section{CONCLUSIONS}

EDR has been studied extensively for the removal of metals from sediments, soils, ashes, and other materials. This manuscript reports total metal removal from heavily contaminated estuarine sediments of up to $95 \%$. However, pH-dependent leaching results under oxic conditions found that many elements were released from treated sediments in concentrations higher than untreated sediments. DOC was found to also be released in higher concentrations from the treated sediments, suggesting influence of the EDR on the high organic matter content of the contaminated sediments, and the DOC complexes represented a significant fraction of total elemental concentration released, particularly in the neutral $\mathrm{pH}$ range. Removal of important sorbent phases (iron and aluminum hydroxides) during EDR may also contribute to observed increases in leaching from treated sediments.

\section{REFERENCES}

APUL, D.S., GARDNER, K.H., and EIGHMY, T.T. (2005). Simultaneous application of dissolution/precipitation and surface complexation/surface precipitation modeling to contaminant leaching. Environ. Sci. Technol. 39(15), 5736.

CHAGUE-GOFF, C. (2005). Assessing the removal efficiency of $\mathrm{Zn}, \mathrm{Cu}, \mathrm{Fe}$, and $\mathrm{Pb}$ in a treatment wetland using selective sequential extraction: A case study. Water Air Soil Pollut. 160(1-4), 161.

DALTON, J.L., GARDNER, K.H., WEIMER, M.L., SPEAR, J.C.M., SEAGER, T.P., and MAGEE, B.J. (2004). Properties of portland cement made from contaminated sediments. Resources Conservat. Recycl. 41, 227.

GRIMM, D.M., AZARRAGA, L.V., CARREIRA, L.A., and SUSETYO, W. (1991). Continuous multiligand distribution model used to predict the stability constant of $\mathrm{Cu}$ (II) complexation with humic material from fluorescence quenching data. Environ. Sci. Technol. 25, 1427.

HARDAWAY C., GAUTHREAUX, K., SNEDDON, J., and BECK, J.N. (1999). Evaluation of contaminated sediments by toxicity characteristic leaching procedure extraction techniques. Microchem. J. 63, 398.

HISENVELD, M. (1991). Innovative techniques for treatment of contaminated soils and sediments. Environment Northern Seas Challenges and Business Opportunities, International Conference and Exhibition, Stavanger, Norway 26, $30 \mathrm{Au}-$ gust 1991.

JAKOBSEN, M.R., FRITT-RASMUSSEN, J., NIELSEN, S., and OTTOSEN, L.M. (2004). Electrodialytic removal of cadmium from wastewater sludge. J. Hazard. Mater. 106B, 127.

KARIUS, V., and HAMER, K. (2001). pH and grain-size variation in leaching tests with bricks made of harbor sediments compared to commercial bricks. Sci. Total Environ. 278, 73.

KOSSON, D.S., VAN DER SLOOT, H.A., SANCHEZ, F., and GARRABRANTS, A.C. (2002). An integrated framework for evaluating leaching in waste management and utilization of secondary materials. Environ. Eng. Sci. 19(3), 159.

LONG, E.R., and MORGAN, L.G. (1991). The potential for biological effects of sediment-sorbed contaminants tested in the National Status and Trends Program. NOAA Technical Memorandum NOS OMA 52.

LONG, E.R., MACDONALD, D.D., SMITH, S.L., and CALDER, F.D. (1995). Incidence of adverse biological effects within ranges of chemical concentrations in marine and estuarine sediments. Environ. Manage. 19(1), 81.

MEIMA, J.A., and COMANS, R.N.J. (1998). Application of surface complexation/precipitation modeling to contaminant leaching from weathered municipal solid waste incinerator bottom ash. Environ. Sci. Technol. 32(5), 688.

MULLIGAN, C.N., YONG, R.N., and GIBBS, B.F. (2001). An evaluation of technologies for the heavy metal remediation of dredged sediments. J. Hazard. Mater. 85, 145. 
NYSTROEM, G.M., OTTOSEN, L.M., and VILLUMSEN, A. (2003). The use of sequential extraction to evaluate the remediation potential of heavy metals from contaminated harbor sediment. J. Phys. IV 107, 975.

NYSTROEM, G.M., OTTOSEN, L.M., and VILLUMSEN, A. (2004). Test of experimental set-ups for electrodialytic removal of $\mathrm{Cu}, \mathrm{Zn}, \mathrm{Pb}$ and $\mathrm{Cd}$ from different contaminated harbour sediments. Eng. Geol. 77(3-4), 349.

NYSTROEM, G.M., OTTOSEN, L.M., and VILLUMSEN, A. (2005a). Electrodialytic removal of $\mathrm{Cu}, \mathrm{Zn}, \mathrm{Pb}$ and $\mathrm{Cd}$ from harbor sediment-The influence of changing experimental conditions. Environ. Sci. Technol. 39, 2906.

NYSTROEM, G.M., OTTOSEN, L.M., and VILLUMSEN, A. (2005b). Acidification of harbour sediment and removal of heavy metals induced by water splitting in electrodialytic remediation. Sep. Sci. Technol. 40(11), 2245.

NYSTROEM, G.M., OTTOSEN, L.M., and VILLUMSEN, A. (2006). The use of desorbing agents in electrodialytic remediation of harbour sediment. Sci. Total Environ. 357, 25.

OSPAR. (1997). Agreement 1997-14: Agreed ecotoxicological assessment criteria for trace metals, PCBs, PAHs, TBT and some organochlorine pesticides. Annex 6, ref 3.14. http://www.ospar.org/eng

OTTOSEN, L.M., HANSEN, H.K., LAURSEN, S., and VILLUMSEN, A. (1997). Electrodialytic remediation of soil polluted with copper from wood preservation industry. Environ. Sci. Technol. 31, 1711.

OTTOSEN, L.M., HANSEN, H.K., and HANSEN, C. (2000). Water splitting at ion-exchange membranes and potential differences in soil during electrodialytic soil remediation. $J$. Appl. Electrochem. 30, 1199.

OTTOSEN, L.M., KRISTENSEN, I.V., PEDERSEN, A.J., HANSEN, H.K., VILLUMSEN, A., and RIBEIRO, A.B. (2003). Electrodialytic removal of heavy metals from different solid waste products. Sep. Sci. Technol. 38(6), 1269.

PEDERSEN, A.J., and GARDNER, K.H. (2003). Characterization of municipal solid waste incineration fly ash before and after electrodialytic treatment. J. Phys. IV France 107, 1029.

PEMPKOWIAK, J., SIKORA, A., and BIERNACKA, E. (1999). Speciation of heavy metals in marine sediments vs. their bioaccumulation by mussels. Chemosphere 32(2), 313.

PELIN, G., BONARDI, M., FABRIS, R., SIMONCINI, B., MANENTE, S., TOSI, L., and SCOTTO, S. (1997). Heavy metal pollution in central Venice Lagoon bottom sediments: Evaluation of the metal bioavailability by geochemical speciation procedure. Environ. Technol. 18(6), 593.

PETERSON, C.H., and BISHOP, M.J. (2005). Assessing the environmental impacts of beach nourishment. Bioscience 55(10), 887 .

SEIDEL, H., LOSER, C., ZEHNSDORF, A., HOFFMANN, P., and SCHMEROLD, R. (2004). Bioremediation process for sediments contaminated by heavy metals: Feasibility study on a pilot scale. Environ. Sci. Technol. 38(5), 1582.

SIMPSON, S.L., and BATLEY, G.E. (2003). Disturbances to metal partitioning during toxicity testing of iron(II)-rich estuarine pore waters and whole sediments. Environ. Sci. Technol. 22(2), 424.

SIMPSON, S.L., ROCHFORD, L., and BIRCH, G.F. (2002). Geochemical influences on metal partitioning in contaminated estuarine sediments. Marine Freshwater Res. 53(1), 9.

STEPHENS, S.R., ALlOWAY, B.J., CARTER, J.E., and PARKER, A. (2001). Towards the characterization of heavy metals in dredged canal sediments and an appreciation of "availability": Two examples from the UK. Environ. Pollut. 113, 395.

U.S. ENVIRONMENTAL PROTECTION AGENCY. (1991). Method for the Determination of Metals in Environmental Samples. EPA/600/4-91/010. Washington, DC: Office of Research and Development.

U.S. ENVIRONMENTAL PROTECTION AGENCY. (1992). Toxicity Characteristic Leaching Procedure, SW-846 Method 1311. Washington, DC: Author.

VAN DER SLOOT, H.A., COMANS, R.N.J., and HJELMAR, O. (1996). Similarities in the leaching behaviour of trace contaminants from waste, stabilized waste, construction materials and soils. Sci. Total Environ. 178, 111.

VANTHUYNE, M., MAIES, A., CAUWENBERG, P. (2003). The use of flotation techniques in the remediation of heavy metal contaminated sediments and soils: An overview of controlling factors. Minerals Eng. 16(11), 1131.

VAN ZOMEREN, A., and COMANS, R.N.J. (2004). Contribution of natural organic matter to copper leaching from municipal solid waste incinerator bottom ash. Environ. Sci. Technol. 38(14), 3927.

WEINSTEIN, M.P., and WEISHAR, L.L. (2002). Beneficial use of dredged material to enhance the restoration trajectories of formerly diked lands. Ecol. Eng. 19(3), 187. 